Folia Geographica Physica 18, 2019: 29-40, http://dx.doi.org/10.18778/1427-9711.18.02

\author{
Paweł Przepióra $^{1}$ (1) • Tomasz Kalicki ${ }^{1}$ () $\bullet$ Sławomir Chwałek $^{1} \bullet$ Geoffrey Houbrechts $^{2}$ \\ (1) Uniwersytet Jana Kochanowskiego w Kielcach, Instytut Geografii i Nauk o Środowisku; (2) University of Liège, Fluvial Geomorphology and Hydrography \\ Research Center \\ E-mail: pawelprzepiora1988@gmail.com; tomaszkalicki@ymail.com; slawomirchwalek@gmail.com; G.Houbrechts@ulg.ac.be
}

\title{
Historyczny układ hydrotechniczny w Jędrowie (województwo świętokrzyskie) zachowany w formach i osadach - studium geoarcheologiczno-konserwatorskie
}

\section{The historic hydrotechnical system in Jędrów (Świętokrzyskie Province) preserved in landforms and sediments - geoarchaeological and conservation study}

\begin{abstract}
Zarys treści
Młyn w Jędrowie jest jednym z niewielu obiektów na terenie Staropolskiego Okręgu Przemysłowego, który zachował się w dobrym stanie. Dotyczy to również pozostałości wciąż widocznej w rzeźbie infrastruktury hydrotechnicznej oraz śladów jej funkcjonowania zachowanych w osadach równiny zalewowej Kamionki. Szczegółowe analizy, z wykorzystaniem specjalistycznych metod badawczych podpartych kwerendą materiałów historycznych, pozwoliły na lokalizację poszczególnych elementów tej infrastruktury, tj. dawny zbiornik, młynówka, wały. Część tej infrastruktury jest dobrze zachowana w rzeźbie i widoczna na numerycznym modelu terenu. Inne ślady po historycznej działalności metalurgicznej widoczne są dopiero po makro- i mikroskopowej analizie osadów jeziornych oraz pozakorytowych, tj. węgielki drzewne, żużle i mikroskopijne kulki żelaza. W miejscu odrestaurowanego młyna lub też w jego pobliżu funkcjonowała kuźnica, o czym świadczą materiały archiwalne. Obecnie młyn jest odrestaurowywany, a badania przedstawione w artykule posłużyły do objęcia tego obiektu wraz z najbliższym otoczeniem ochroną konserwatorską jako zabytku techniki.
\end{abstract}

Słowa kluczowe Jędrów, żużel, osady jeziorne, Kuźnica, Staropolski Okręg Przemysłowy.

Abstract

\begin{abstract}
The water mill is one of the few objects in the Old Polish Industrial District that have been preserved in good condition. This also applies to the remains of hydrotechnical infrastructure that are still visible in the relief and traces of its functioning preserved in the sediments of the Kamionka River floodplain. Detailed analyzes using specialized research methods supported by a query of historical materials revealed the location of individual elements of this infrastructure, i.e. former reservoir, mill race, dyke. Part of this infrastructure is well preserved in the relief and visible on the digital elevation model. Other historical metallurgical activity traces are only visible after macro- and microscopic analysis of lacustrine and overbank sediments, i.e. charcoals, slags and microscopic iron balls. A forge operated in the place of the restored mill or nearby, as proven by archival materials. Currently, the water mill is being restored, and the research presented in the article was used to take this object along with the nearest surroundings under protection as a technical monument.
\end{abstract}

Keywords

Jędrów, slag, lacustrine sediments, forge, Old Polish Industrial District.

\section{Wprowadzenie}

Wpływem czynnika antropogenicznego na środowisko geograficzne dolin rzecznych z uwzględnieniem zmian w formach i osadach zajmowało się wielu autorów (m.in. Macklin i in. 1992, Schirmer 1995, Starkel, Krąpiec 1995, Herget 1998, Klimek 1999, 2003, Marchetti 2002, Kalicki 2006, Houben i in. 2009, Notebaert i in. 2011, 2013, Rutkiewicz i in. 2017, 2019, Aksamit i in. 2019, Kalicki i in. 2019b, 2019c). Zagadnienie to często jest związane z działalnością przemysłową, w tym również hutnictwem, które rozwijało się w wielu miejscach w Europie na przestrzeni wielu stuleci, np. w Polsce (m.in. Kalicki i in. 2019b), czy w innych krajach Europy, np. w Belgii (m.in. Houbrechts, Petit 2003, 2004, Houbrechts i in. 2003, 2004). Hutnictwo rozwijało się na terenie Polski już w czasach prehistorycznych (Bielenin 1993, Orzechowski 2007), ale dopiero jego intensywny rozwój w średniowieczu aż do końca XIX wieku pozostawił bardzo wyraźne piętno w krajobrazie Staropolskiego Okręgu Przemysłowego (Zieliński 1965). Pomimo wyraźnej zapaści górnictwa i hutnictwa w tym regionie, w niektórych miejscach wydobycie i przetwarzanie rudy żelaza prowadzone było nawet do pierwszej połowy XX wieku. W bezpośrednim sąsiedztwie kuźnic lub na ich miejscu wznoszono młyny wodne, których działalność również wywierała bardzo duży wpływ na przekształcenia wielu systemów rzecznych (m.in. Łoś 1978, Kaniecki 1999, Podgórski 2004, Krupa 2013, 2015, Kusztal i in. 2017a, 2017b, Chrabąszcz i in. 2017, Mięsiak-Wójcik 2018, Kalicki i in. 2019c). 
Doskonałym przykładem tego typu sytuacji są okolice młyna w Jędrowie (województwo świętokrzyskie), gdzie zachowała się wyraźna niecka dawnego stawu przemysłowego, przy którym działała niegdyś kuźnica. Działalność zakładu metalurgicznego w tym miejscu potwierdzają również liczne materiały kartograficzne. Stare mapy z różnych okresów pokazują liczne zmiany koryta Kamionki spowodowane działalnością kuźnicy oraz młyna (regulacja rzeki, powstanie i zanik stawów) (Przepióra 2017, Przepióra, Kalicki 2018, Kalicki i in. 2019c, 2019d).

Obecnie po wielu latach młyn w Jędrowie wraz z częścią jego dawnej infrastruktury hydrotechnicznej został odrestaurowany i trwają prace mające na celu wpisanie tego obiektu do listy zabytków (Kalicki, Przepióra 2019).
W związku z tym wykonano szereg badań, które miały za zadanie określić zasięg pozostałej infrastruktury zachowanej $w$ formach terenu i osadach.

\section{Lokalizacja i charakterystyka obszaru}

Młyn w Jędrowie leży w środkowej części zlewni Kamionki. Jest to meandrująca, górska rzeka o długości ok. 17 km w północnej części województwa świętokrzyskiego (powiat Skarżysko-Kamienna, gmina Suchedniów) (ryc. 1). Analizowany obszar usytuowany jest na Płaskowyżu Suchedniowskim (342.31), będącym częścią Wyżyny Kieleckiej (342.2) (Kondracki 1977, 2002).

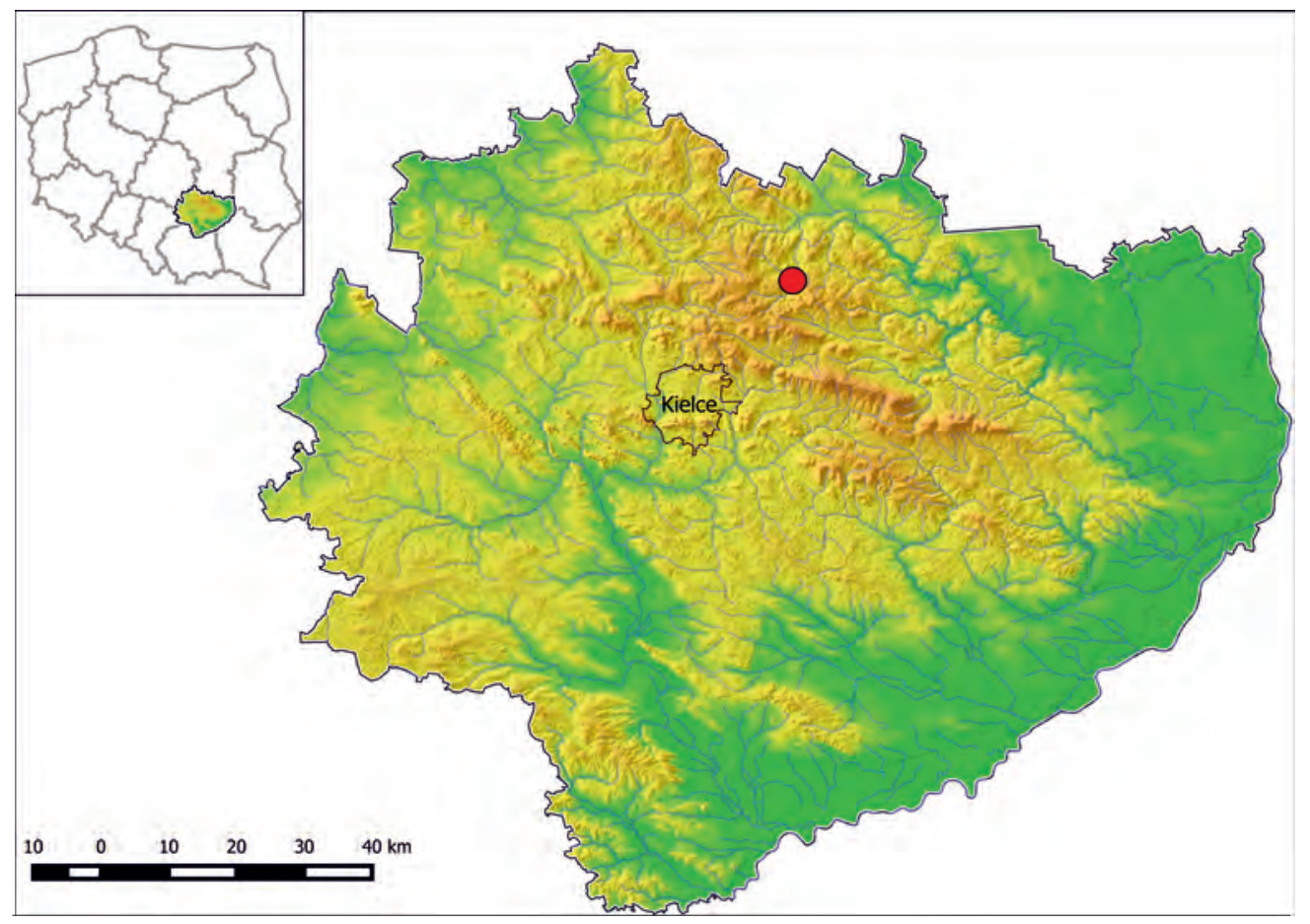

Ryc. 1. Położenie obszaru badawczego; oprac. M. Frączek na podstawie danych pozyskanych z CODGiK (MGGP Aero, $\mathrm{Nr}$ GI-FOTO.703.44.2014)

Fig. 1. Location of the study area; ed. by M. Frączek based on data from CODGiK (MGGP Aero, No. GI-FOTO.703.44.2014)

Obszar badań położony jest w dolinie Kamionki, u wylotu z przełomu między wzgórzami zbudowanymi z piaskowców triasowych, a przed rozszerzeniem doliny w Kotlinie Suchedniowskiej, wypełnionej piaskami wodnolodowcowymi i przy zboczach gliną zwałową (ryc. 2). Nieco poniżej młyna wpada do Kamionki jej lewobrzeżny dopływ - Łosiennica.

Z obu stron doliny zachowana jest plejstoceńska terasa 5-6 m n.p. rzeki zbudowana z piasków i żwirów rzeki roztokowej, lokalnie z wkładkami osadów stokowych, jak dokumentuje to profil poniżej Suchedniowa (Kalicki i in. 2017). Krawędzie terasy o kilkumetrowej wysokości porozcinane są erozyjnymi dolinkami, większymi (plejstoceńskimi) i mniejszymi (holoceńskimi), a także antropogenicznymi wyrobiskami (piaskowniami), których powstanie może być związane z okresem budowy kuźnicy lub młyna (ryc. 3). Młyn usytuowany jest na równinie zalewowej (ok. 1 m n.p.r.) zbudowanej z holoceńskich aluwiów rzeki meandrującej (Przepióra, Kalicki 2018).
Młyn wraz z pozostałą infrastrukturą hydrotechniczną położony jest na wąskiej (ok. 200 m) równinie zalewowej, na której zachowały się niewielkie starorzecza. W rzeźbie widoczne są również bardzo wyraźnie formy antropogeniczne (młynówka, wały, stawy, pozostałości śluzy) będące w większości pozostałościami po dawnej infrastrukturze hydrotechnicznej młyna i zapewne wcześniejszej kuźnicy (Przepióra i in. 2018).

Jędrów był niewielką wsią powstałą w miejscu funkcjonowania kuźnicy Andrissa, a obecnie jest częścią Suchedniowa, do którego został włączony jako jego południowy przysiółek. We wschodniej części Jędrowa dominuje zabudowa wiejska i pojedyncze domy jedno- i dwurodzinne, natomiast w zachodniej dominują łąki, nieużytki, a rzadziej, wciąż użytkowane, pola uprawne. W środkowej części osady znajduje się ceglany młyn zbudowany na prawym brzegu Kamionki. 


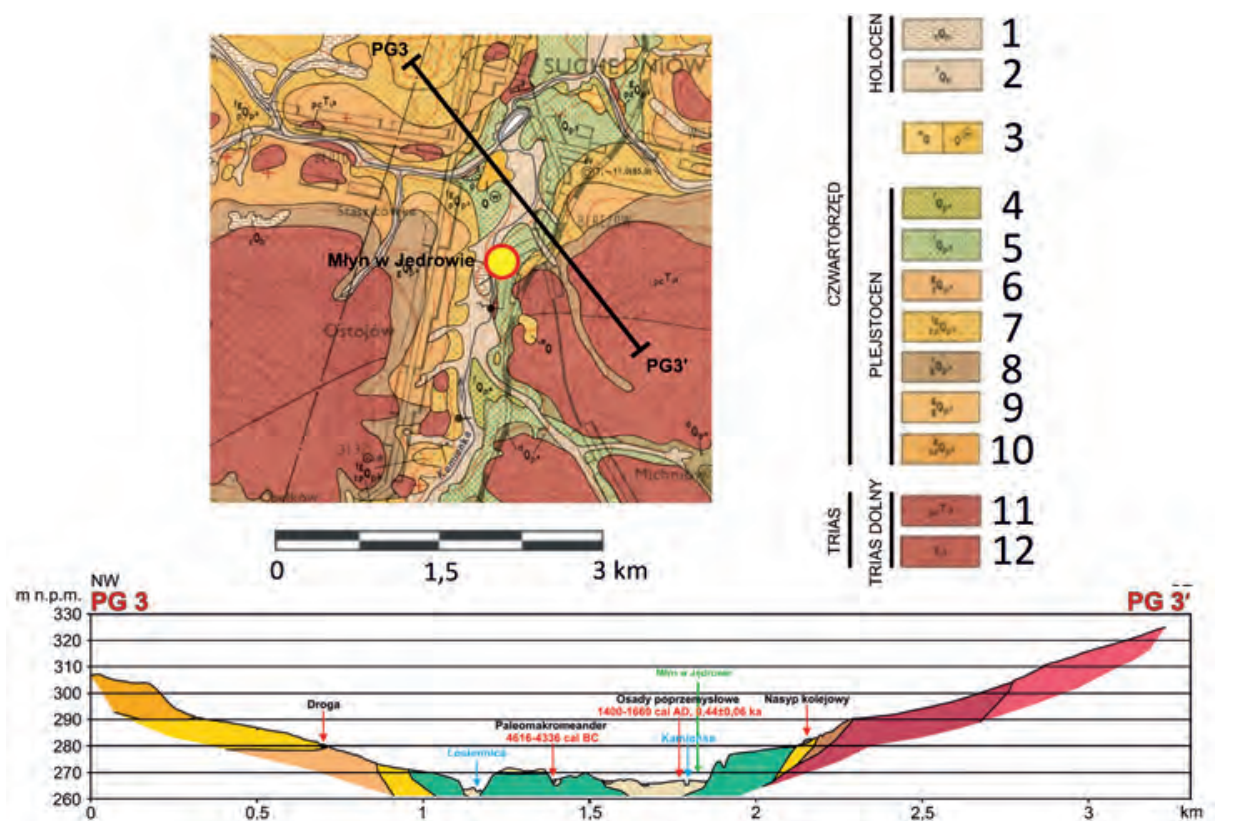

Ryc. 2. Wycinek szczegółowej mapy geologicznej 1:50000 obszaru zlewni, arkusz 779, Skarżysko-Kamienna (Filonowicz 1978a, 1978b) oraz przekrój geologiczny przez dolinę Kamionki w pobliżu omawianego obszaru (Przepióra 2017). Objaśnienia do mapy geologicznej:

1 - torfy i namuły torfiaste, 2 - osady rzeczne w ogólności, 3 - piaski eoliczne: piaski eoliczne w wydmach, 4 - piaski rzeczne terasów 3-5 m n.p. rzeki, 5 - piaski i żwiry rzeczne $z$ soczewkami glin soliflukcyjnych i otoczakami w stropie, 6 - żwiry i głazy lodowcowe, 7 - żwiry i piaski wodnolodowcowe, 8 - gliny ilaste i gliny piaszczyste z otoczakami piaskowców, zwietrzelinowe, 9 - gliny zwałowe, 10 - piaski i gliny lodowcowe, 11 - piaskowce z wkładkami iłów, mułowców i pseudoolitów oraz szare łupki z odciskami roślin, 12 - piaskowce i mułowce

Fig. 2. Fragment of a 1:50,000 geological map of the catchment area, sheet 779, Skarżysko-Kamienna (Filonowicz 1978a, 1978b) and a geological cross-section through the Kamionka valley near the discussed area (Przepióra 2017). Explanations to the geological map: 1 - peats and peaty silts, 2 - river sediments in general, 3 - aeolian sands: aeolian sands in dunes, 4 - river sands of terraces 3-5 m above river level, 5 - sands and river gravels with lenses of soliflution clays and pebbles in the top, 6 - glacial gravels and boulders, 7 - gravel and glacial sands, 8 - clay loams and sandy loams with sandstone pebbles, waste, 9 - tills, 10 - sands and glacial clays, 11 - sandstones with clays, mudstones and pseudoolites, and gray slates with plant prints, 12 - sandstones and mudstones

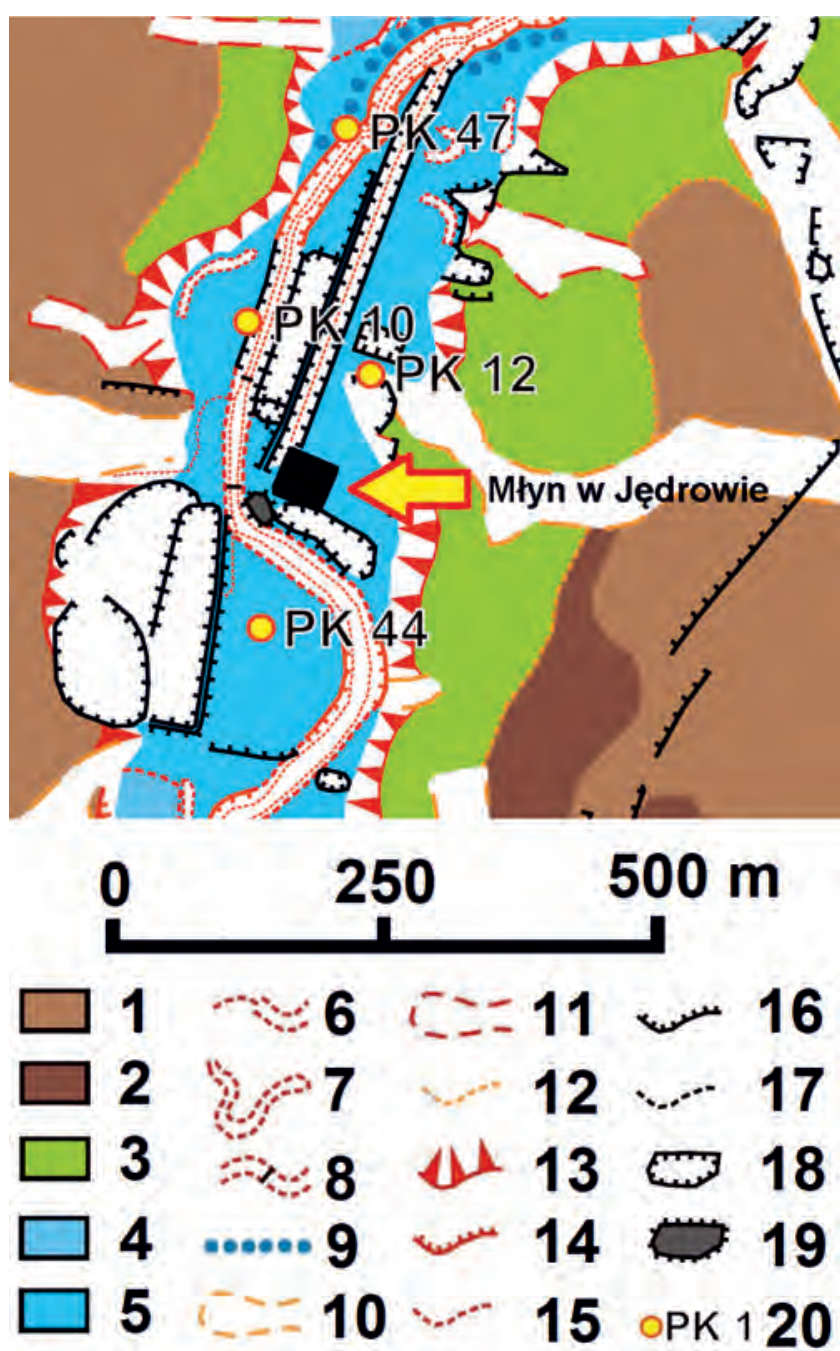

Ryc. 3. Wycinek mapy geomorfologicznej (Przepióra 2017). Objaśnienia do mapy geomorfologicznej: 1 - stok o nachyleniu $2-6^{\circ}, 2$ - stok o nachyleniu powyżej $6^{\circ}, 3$ - plejstoceńska terasa (3-5 m n.p.r.), 4 - równina zalewowa ( $2 \mathrm{~m}$ n.p.r.), 5 - równina zalewowa (1 m n.p.r.), 6 - koryto rzeczne, 7 - starorzecze holoceńskie, 8 - progi i jazy na rzece, 9 - wał przykorytowy, 10 - plejstoceńskie doliny fluwialno-denudacyjne, 11 - holoceńskie doliny fluwialno-denudacyjne, 12 - słabo widoczne krawędzie plejstoceńskie, 13 - większe krawędzie holoceńskie, 14 - krawędzie holoceńskie, 15 - słabo widoczne krawędzie holoceńskie, 16 - krawędzie antropogeniczne, 17 - słabo widoczne krawędzie antropogeniczne, 18 - antropogeniczne obniżenia, kopalnie odkrywkowe, wyrobiska, misy sztucznych zbiorników wodnych, 19 - antropogeniczne wyniesienia, hałdy

Fig. 3. A part of the geomorphological map (Przepióra 2017). Explanations for the geomorphological map: 1 - slope with a 2-6 gradient, 2 - slope with more than $6^{\circ}$ gradient, 3 - Pleistocene alluvial terraces (3-5 $\mathrm{m}$ a.r.l.) , 4 - floodplain ( $2 \mathrm{~m}$ a.r.l.), 5 - floodplain (1 $\mathrm{m}$ a.r.l.), 6 - riverbed, 7 - Holocene paleochannel, 8 - thresholds and weirs on the river, 9 -levee, 10 - Pleistocene fluvio-denudational valleys, 11 - Holocene fluvio-denudational valleys, 12 - blurred Pleistocene edges, 13 - bigger Holocene edges, 14 - Holocene edges, 15 - blurred Holocene edges, 16 - anthropogenic edges, 17 - blurred anthropogenic edges, 18 - anthropogenic depressions, opencast mines, excavations, artificial water reservoirs, 19 - heaps and embankments 


\section{Cel i metody badań}

Celem artykułu jest rozpoznanie śladów powstałych w okresie działalności obecnie odrestaurowanego młyna i dawnej, nieistniejącej już kuźnicy, zachowanych w formach i osadach równiny zalewowej Kamionki w pobliżu Jędrowa. W tym celu posłużono się następującymi metodami badawczymi:

\section{Metody terenowe:}

- kartowanie geomorfologiczne,

- odwierty i profile geologiczne (wiertnia ręczna Eijkelkamp),

- analiza geofizyczna (Georadar ProEx firmy MALA z anteną $500 \mathrm{Mhz})$.

Metody laboratoryjne:

- analiza granulometryczna (zestaw sit testowych (2800-63 $\mu \mathrm{m}$ ) oraz wytrząsarki laboratoryjne firmy Retsh oraz Morek-Multiserw),

- datowanie osadów metodą TL/OSL (analizator naturalnych radionuklidów typ MAZAR - 01 oraz Laboratoryjne Czytniki Materiałów TL/OSL RA'04 Reader/Analyser),

- datowanie metodą 14C (wykonane w Laboratorium Datowań Bezwzględnych w Skale),

- separacja makro- i mikroskopijnych fragmentów żużla z osadów pozakorytowych i jeziornych (przedział 600-212 $\mu \mathrm{m}$ ) oraz ferromagnetycznych pozostałości po działalności metalurgicznej w formie mikroskopijnych kulek żelaza (przedział 212-63 $\mu \mathrm{m}$ ).

Metody kameralne:

- kwerenda materiałów historycznych,

- kwerenda materiałów publikowanych i niepublikowanych (artykuły, dokumentacje, praca doktorska w archiwum UJK),

- opracowanie graficzne map tematycznych.

\section{Wyniki badań}

\subsection{Historia młyna}

Kamionka już od czasów średniowiecza była intensywnie wykorzystywana przez człowieka jako źródło zasilania pobliskich zakładów metalurgicznych oraz młynów zbożowych funkcjonujących w granicach Staropolskiego Okręgu Przemysłowego (ryc. 4A). Wydobycie rudy żelaza na okolicznych wzgórzach spowodowało budowę licznych kuźnic wzdłuż całej rzeki. W całym dorzeczu Kamionki występowało ok. 7 kuźnic (ryc. 4B) (Bielenin 1993, Przepióra 2017). Jedna z nich funkcjonowała w miejscu obecnego młyna w Jędrowie. Pierwsze wzmianki o kuźnicy w tym miejscu pochodzą z 1530 roku, natomiast informacje o samym młynie pojawiają się w 1859 roku. W 1863 roku drewniana konstrukcja została spalona, a obecny, ceglany budynek funkcjonuje od 1911 roku (Piasta 2012, Przepióra 2017).

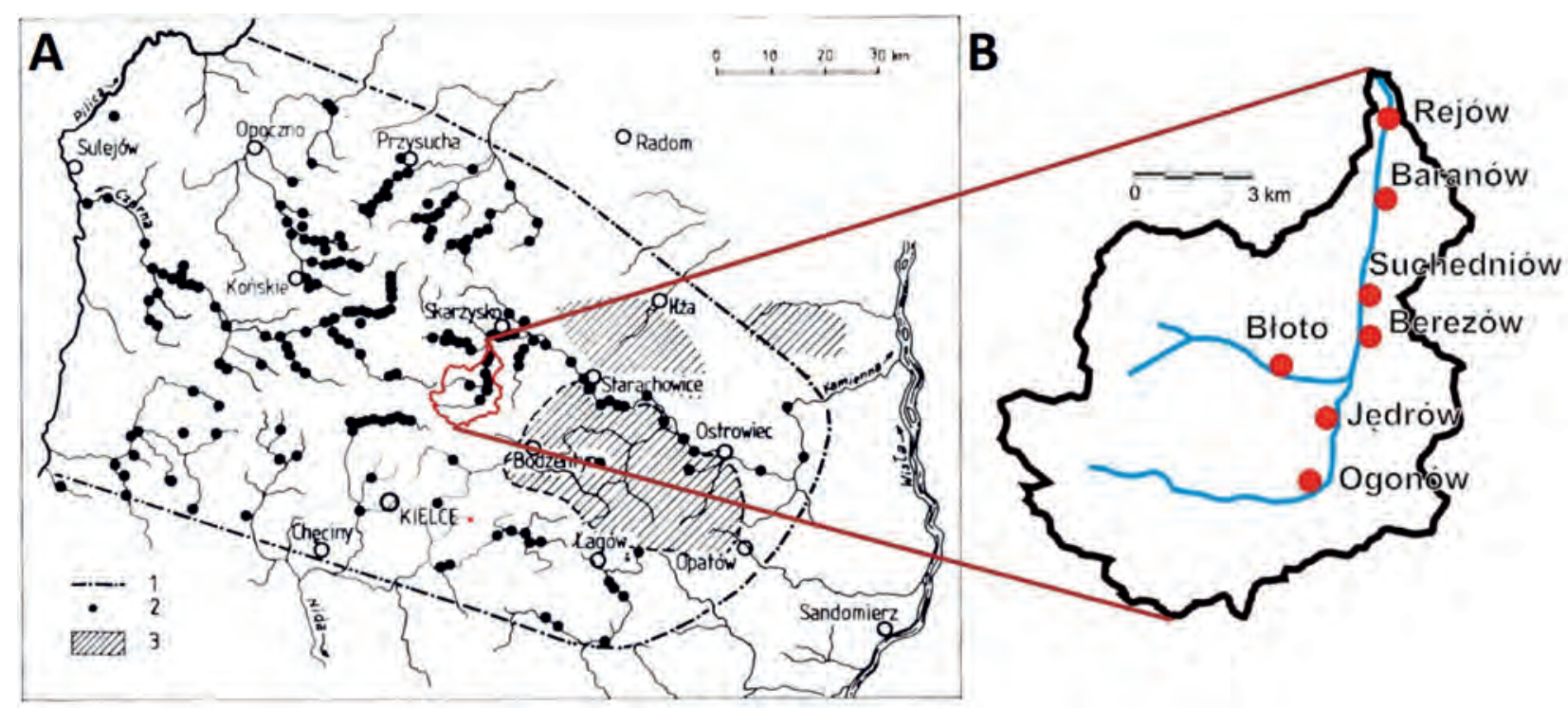

Ryc. 4. Lokalizacja zlewni Kamionki w granicach Staropolskiego Okręgu Przemysłowego (SOP) wg. Radwana (A) (Bielenin 1993); 1 - granice SOP, 2-kuźnice, 3 - obszar działalności dymarskiej (hutnictwo prehistoryczne) oraz dokładne rozmieszczenie kuźnic na obszarze zlewni Kamionki w XVI w. w oparciu o mapę Zagłębia Staropolskiego (B) (Bielenin 1993, oprac. Przepióra 2017)

Fig. 4. Location of the Kamionka catchment in the boundaries of the Old Polish Industrial District (OPID) by Radwan (A) (Bielenin 1993); 1 - OPID boundaries, 2 - forges, 3 - bloomery development area (prehistoric smelting) and the exact location of forges in the Kamionka catchment area in the $16^{\text {th }}$ C. based on the map of the Old Polish Industrial District (B) (Bielenin 1993, ed. by Przepióra 2017)

Funkcjonowanie w tym miejscu kuźnicy, a następnie młyna potwierdzają liczne materiały archiwalne, w tym kartograficzne (Przepióra i in. 2017, 2018), m.in. mapy Carte de la Pologne z 1772 roku (ryc. 5A) czy Karty dawnej Polski z 1859 roku (ryc. 5B).

Powstanie w środkowej części zlewni centrów metalurgicznych przyczyniło się do licznych przekształceń rzeźby terenu, w tym do przeobrażenia niektórych odcinków koryta. Przeważnie były to sztuczne kanały, młynówki oraz stawy o różnych rozmiarach. Niektóre zbiorniki wodne były wielokrotnie przebudowywane. Mniejsze zbiorniki były osuszane lub ich przeznaczenie ulegało zmianie (ryc. 6). Po wielu pozostała jedynie stara infrastruktura funkcjonujących przy nich młynów. Młyn w Jędrowie wraz z otaczającym go terenem doskonale wpisuje się w przedstawiony wcześniej opis. 


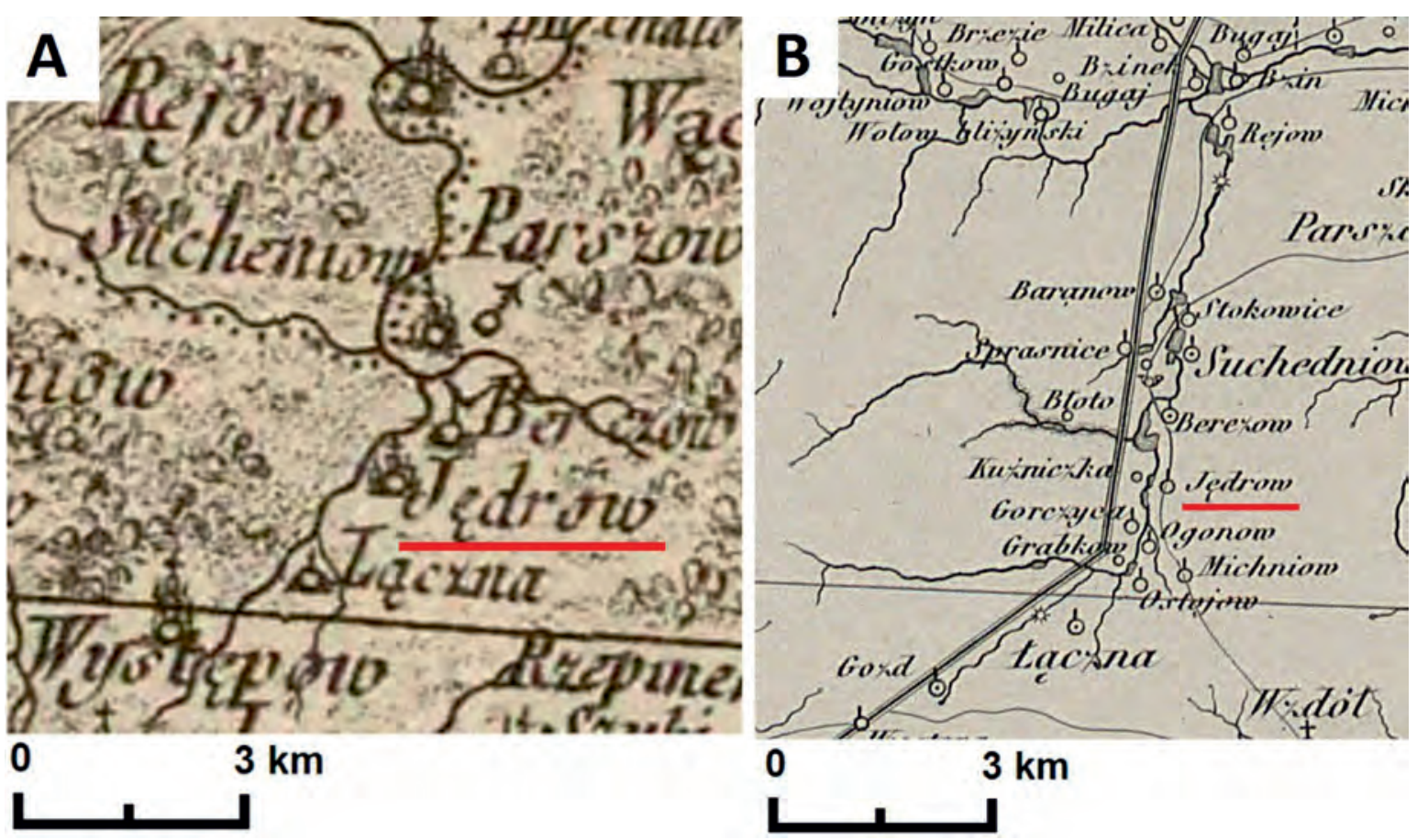

Ryc. 5. Obszar zlewni Kamionki przedstawiony na wycinku mapy Carte de la Pologne (A) (Rizzi Zannoni 1772) oraz rozmieszczenie zakładów hutniczych i młynów w połowie XIX wieku na wycinku Karty dawnej Polski (B) (Chrzanowski 1859, oprac. Przepióra 2017)

Fig. 5. The Kamionka catchment area shown a fragment of the Carte de la Pologne map (A) (Rizzi Zannoni 1772) and the location of metallurgical facilities and water mills in the middle of the $19^{\text {th }} \mathrm{C}$. on a fragment of the Map of Ancient Poland (B) (Chrzanowski 1859, ed. by Przepióra 2017)
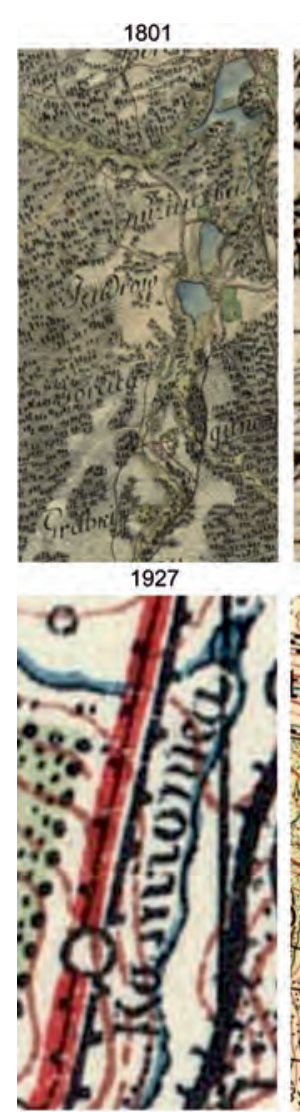

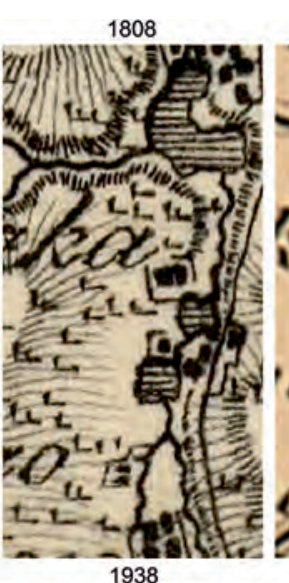

1938

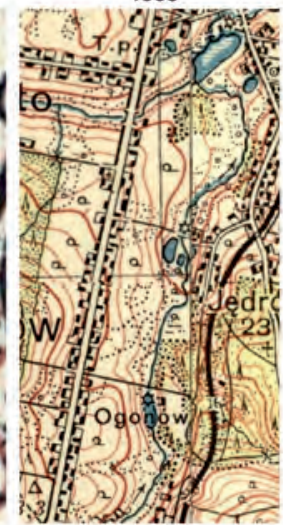

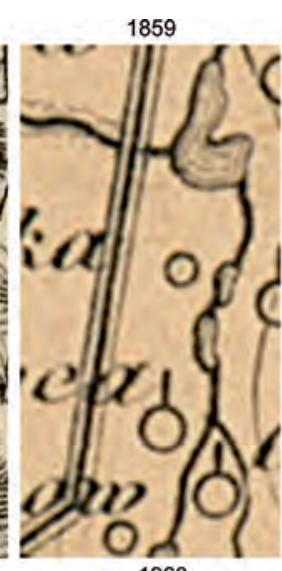

1960

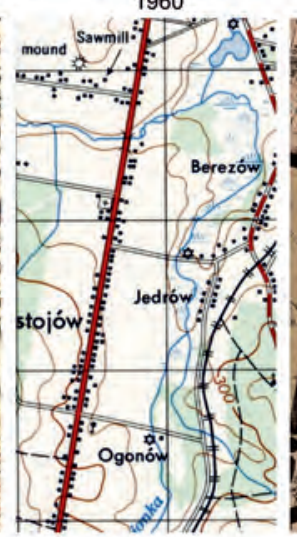

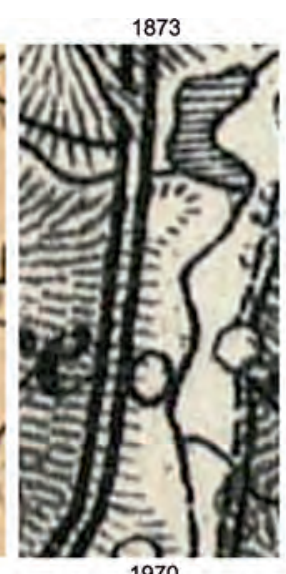

1970

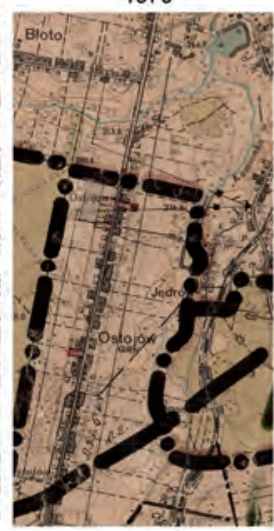

1881

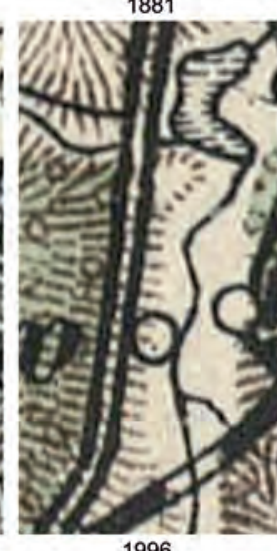

1996

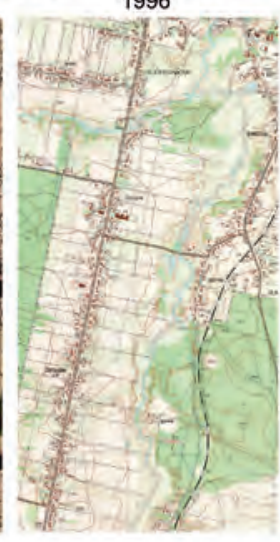

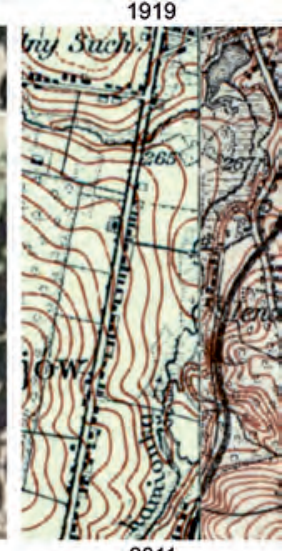

2011

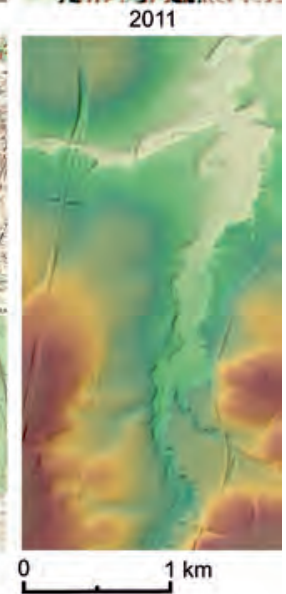

Ryc. 6. Zmiany koryta Kamionki na przestrzeni ostatnich stuleci w oparciu o materiały kartograficzne na odcinku rzeki w pobliżu Jędrowa (Przepióra, Kalicki 2018)

Fig. 6. The Kamionka riverbed changes over the last centuries based on cartographic materials of the river section near Jędrów (Przepióra, Kalicki 2018) 
W miejscach funkcjonowania kuźnic i młynów, napędzanych energią wodną, wznoszono zapory i jazy na rzece oraz powstawały niewielkie stawy przemysłowe. Na przełomie XIX i XX wieku przemysł metalurgiczny oparty na kuźnicach i fryszerkach upadł, co doprowadziło do porzucenia i niszczenia infrastruktury hydrotechnicznej. Do połowy XX wieku funkcjonowały jeszcze tylko nieliczne młyny, a po ich upadku nastąpiło niszczenie zapór na rzece i osuszenie stawów. Często resztki betonowych konstrukcji trafiały do koryta. Na krótkich odcinkach rzeki poniżej dawnych zapór nastąpiła zmiana rozwinięcia koryta - zaczęły formować się bystrza i plosa (step-pool system). Za przykład takiej transformacji może służyć odcinek Kamionki przy starym młynie w Jędrowie poniżej zapory (ryc. 7). W miejscu dawnych, wypełnionych osadami i osuszonych stawów powstawała równina zalewowa, tak jak miało to miejsce w Jędrowie.

W 2016 roku odrestaurowano zaporę przy młynie w Jędrowie. Przyczyniło się to do ponownego zalania fragmentu obszaru, gdzie niegdyś znajdował się historyczny staw. Prowadzone prace renowacyjne młyna i odbudowa zapory prowadzi do kolejnych przemian koryta Kamionki na tym odcinku (Przepióra 2017).

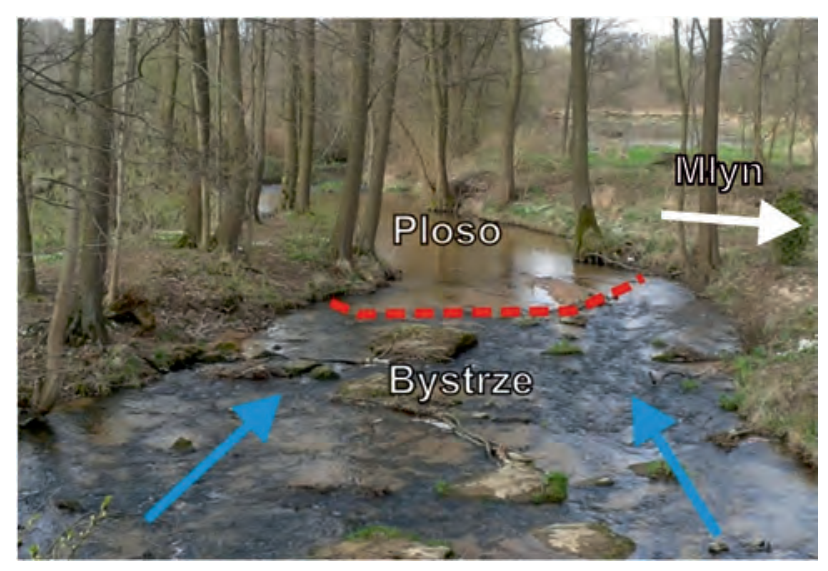

Ryc. 7. Odcinek rzeki w Jędrowie, gdzie zdeponowane zostały pozostałości po betonowej zaporze. Powstały w tym miejscu bystrza i znajdujące się kilkanaście metrów niżej plosa. Strzałki wskazują kierunek płynięcia rzeki. Fotografia została wykonana z pomostu na nowej zaporze w 2016 roku (Przepióra 2017)

Fig. 7. A river section in Jędrów, where the remains of a concrete dam elements were deposited. A riffle formed in this place and a stream pool a dozen meters downstream. The arrows show the direction of the river flow. The photo was taken from the bridge on the new dam in 2016 (Przepióra 2017)

\subsection{Formy i osady}

Ślady poprzemysłowej przeszłości Jędrowa znajdowane są w aluwiach równiny zalewowej na północ od młyna. Są to głównie liczne fragmenty ceramiki współczesnej (ryc. 8A) oraz żużle (ryc. 8B) zalegające w wypełnieniach starorzeczy (ryc. 8C, ryc. 8D) (Przepióra 2017).

W profilu wykonanym na brzegu Kamionki, bliżej ujścia młynówki, występują osady starorzeczne przykryte osadami pozakorytowymi. Widoczne są w nich trzy ciemniej- sze, jasnobrązowe warstwy z wkładkami węgli drzewnych o rozmiarach ok. $2 \mathrm{~cm}$. Stosunkowo duże rozmiary węgli oraz ich znaczne nagromadzenia mogą być związane z bliskim sąsiedztwem dawnej kuźnicy w miejscu obecnego młyna w Jędrowie. Datowania metodą OSL $(0,44 \pm 0,06$ ka; UJK-OSL-68) oraz ${ }^{14} \mathrm{C}(40 \pm 80$ BP czyli 1799-1943 cal. AD; MKL-3250) sugerują, że materiał ten odkładał się w okresie budowy w tym miejscu pierwszych kuźnic (ryc. 9) (Przepióra 2017, Kalicki i in. 2019c).

Na obecnej równinie zalewowej na południowy zachód od młyna widoczne są ślady po dawnych zbiornikach wodnych. Zbiorniki te zapewniały energię dla napędzanych kołem wodnym młynów, kuźnic i fryszerek. Obszar ten jest otoczony fragmentami wałów ziemnych (najpewniej pozostałości stawów hodowlanych, podobnie jak na północ od młyna) (ryc. 10). Stawy te istniały jeszcze w drugiej połowie XX wieku, lecz po osuszeniu stały się one częścią równiny zalewowej. Lokalnie ślady po tych stawach są słabo widoczne i ich zlokalizowanie umożliwiają dopiero odwierty, w których spotykane są czasem miąższe warstwy złożone z odpadów poprodukcyjnych (żużli), czego przykładem jest obszar dawnego stawu w pobliżu młyna w Jędrowie (ryc. 11) (Przepióra 2017, Kalicki i in. 2019a, 2019c).

Odkryty w osadach jeziornych żużel (ryc. 11) potwierdza funkcjonowanie kuźnicy w miejscu obecnego młyna w Jędrowie lub w jego bezpośrednim sąsiedztwie. Do końca lat 70. ubiegłego wieku znajdował się tu niewielki staw młyński (Przepióra 2017).

Obszar dawnego stawu został przeanalizowany z użyciem nieinwazyjnej metody geofizycznej georadaru. Wykonano łącznie 4 echogramy, których rozmieszczenie uwarunkowane było objęciem całego obszaru niecki dawnego zbiornika (ryc. 12). Szczegółowa analiza wygenerowanych echogramów pozwoliła na zlokalizowanie m.in. granic dawnego zbiornika wodnego oraz zmiany w osadach wypełniających jego dno.

Pierwsze trzy echogramy poprowadzono wszerz misy dawnego zbiornika w kierunku wschód-zachód. Przekrój PJ1 (ryc. 12, ryc. 13) usytuowany jest w południowej części badanego obszaru i ma długość ok. $110 \mathrm{~m}$. Maksymalny zasięg sygnału sięga ok. 4 m w głąb gruntu, natomiast większość anomalii widoczna jest do głębokości ok. $2 \mathrm{~m}$. Od ok. 20. metra (dystans) do końca profilu widoczny jest jeden ciąg anomalii sięgający do $3 \mathrm{~m}$ głębokości, natomiast na 35. metrze widoczna jest anomalia, która sięga do 4 m głębokości. Przekrój PJ3 (ryc. 12, ryc. 13) zlokalizowany jest w środkowej części zbiornika i ma długość 110 m. Maksymalny zasięg sygnału również sięga ok. 4 m głębokości. Anomalie w tym echogramie są widoczne do maksymalnie $3 \mathrm{~m}$ głębokości i ich największa liczba znajduje się we wschodniej części przekroju. Kolejny echogram PJ4 (ryc. 12, ryc. 13) wykonano w północnej części dawnego zbiornika. Przekrój ten jest krótszy ze względu na zwężanie się misy zbiornika i wynosi ok. $80 \mathrm{~m}$. Maksymalny zasięg sygnału ma ok. 3,5 m głębokości. Na ok. 1 m głębokości widoczna jest anomalia, która zaczyna się na początku profilu i kończy na ostatnim metrze przekroju. 


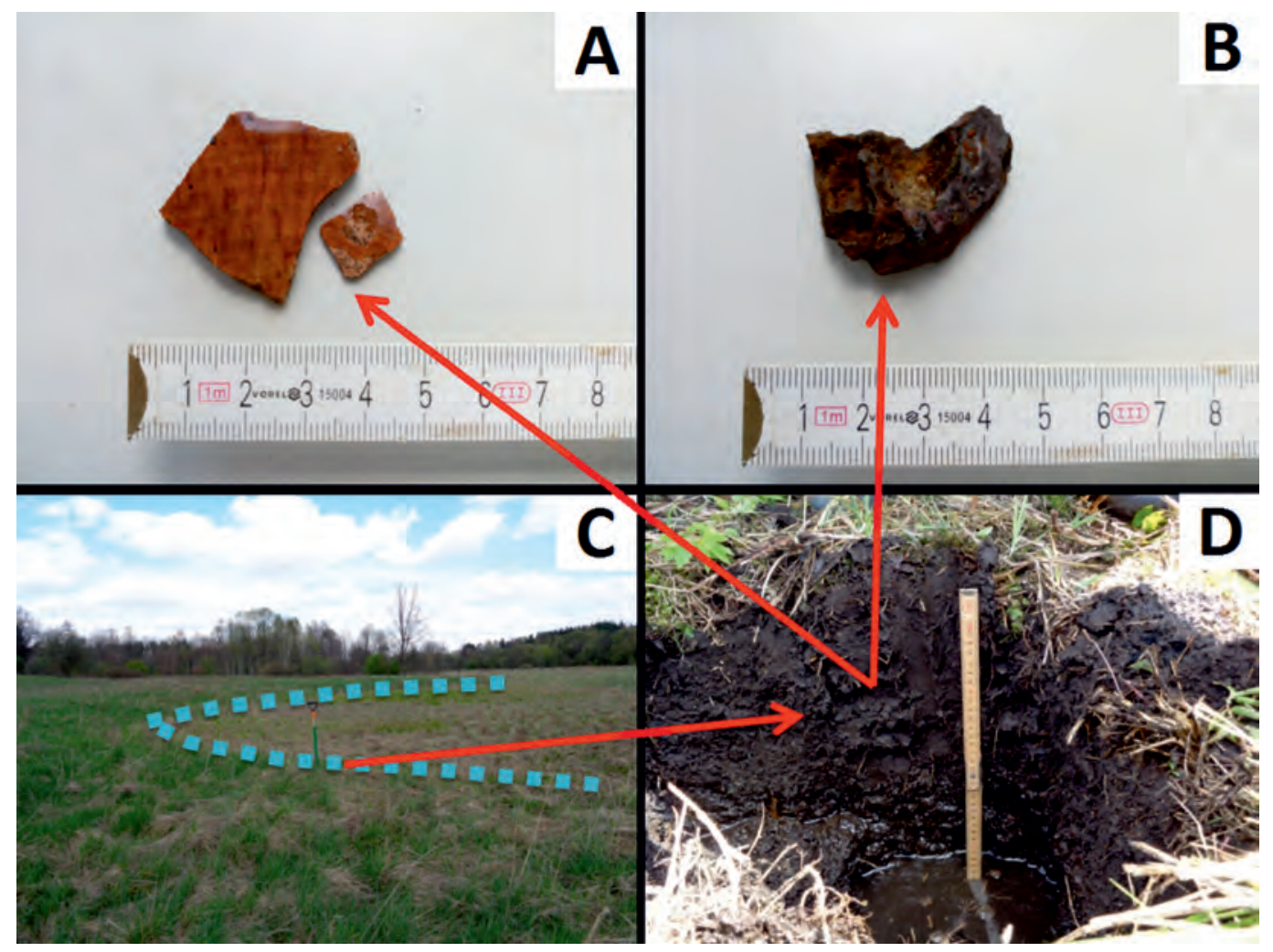

Ryc. 8. Liczne fragmenty współczesnej ceramiki (A) i żużli (B) zalegające w osadach wypełnienia młodego paleomeandra (C) w słabo rozłożonych torfach (D)

Fig. 8. Numerous fragments of modern ceramics (A) and slags (B) lying in the sediments filling the young paleomeander (C) in poorly decomposed peat (D)

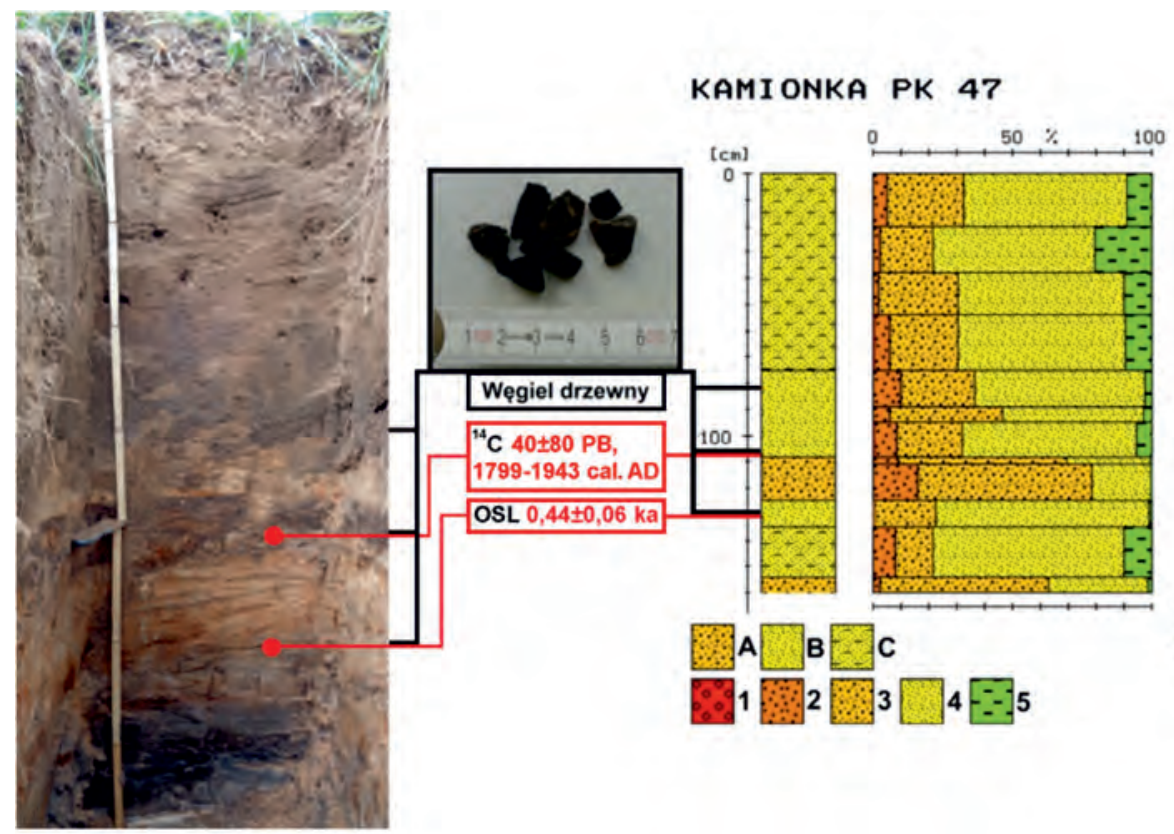

$\varnothing$ $, 1,2,4$

Ryc. 9. Profil PK 47 wykonany przy korycie rzeki nieopodal Jędrowa, granulometria i datowania OSL $i{ }^{14} \mathrm{C}$

Litologia: A - piaski średnie, B - piaski drobne, C - piaski zaglinione; frakcje: 1 - żwir $(<-1 \phi), 2$ - piaski grube $(-1-1 \phi)$, 3 - piaski średnie $(1-2 \phi), 4$ - piaski drobne $(2-4 \phi), 5$ - pyły i iły $(>4 \phi)$; Parametry Folka-Warda: $\mathrm{Mz}$ - średnia średnica, $\delta_{1}$ - odchylenie standardowe, $\mathrm{Sk}_{1}$ - skośność, $\mathrm{K}_{\mathrm{G}}$ - kurtoza; (Przepióra 2017)

Fig. 9. PK 47 profile made near the river bed in Jędrów, granulometry and OSL and ${ }^{14} \mathrm{C}$ datings

Lithology: A - medium sands, B - fine sands, C - silty sands; fractions: 1 - gravels $(<-1 \phi), 2$ - coarse sands $(-1-1 \phi)$, 3 - medium sands $(1-2 \phi), 4-$ fine sands $(2-4 \phi), 5-$ silts and clays $(>4 \phi)$; Folk-Ward's distribution parameters of grain size: $\mathrm{Mz}$ - mean size, $\delta_{1}-$ standard deviation, $\mathrm{Sk}_{1}$ - skewness, $\mathrm{K}_{\mathrm{G}}$ - kurtosis; (Przepióra 2017) 


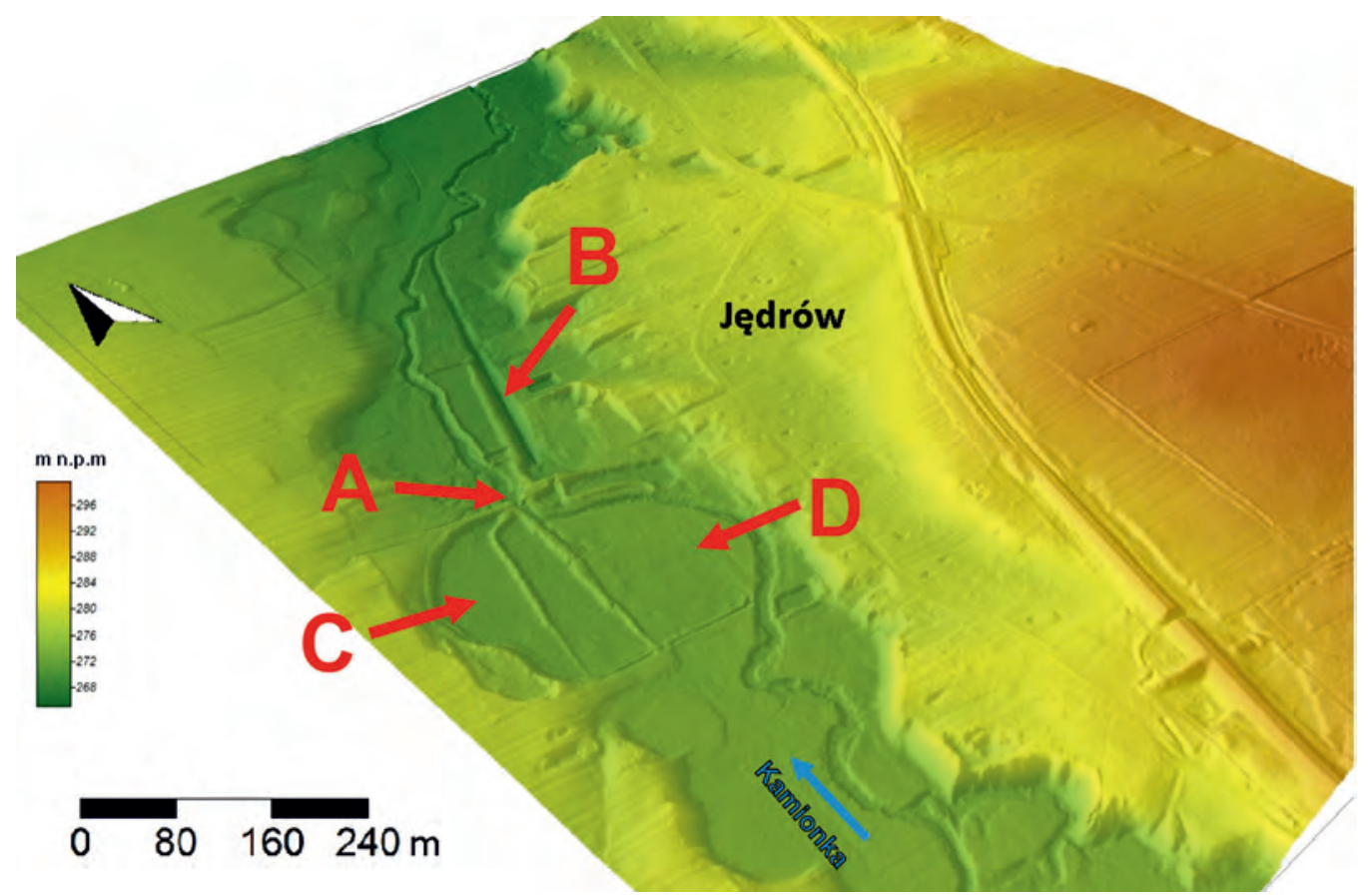

Ryc. 10. Rozmieszczenie głównych elementów infrastruktury hydrotechniczej na badanym obszarze; A - budynek młyna oraz jaz na rzece, B - młynówka, C - dawny zbiornik hodowlany z zachowanymi groblami, D - misa dawnego zbiornika przemysłowego; oprac. M. Frączek na podstawie danych pozyskanych z CODGiK (MGGP Aero, Nr GI-FOTO.703.44.2014)

Fig. 10. Location of the main elements of hydrotechnical infrastructure in the studied area; A - water mill building and weir on the river, B - mill race, $\mathrm{C}$ - former fish reservoir with preserved dykes, D - former industrial reservoir area; ed. by M. Frączek based on data from CODGiK (MGGP Aero, No. GI-FOTO.703.44.2014)

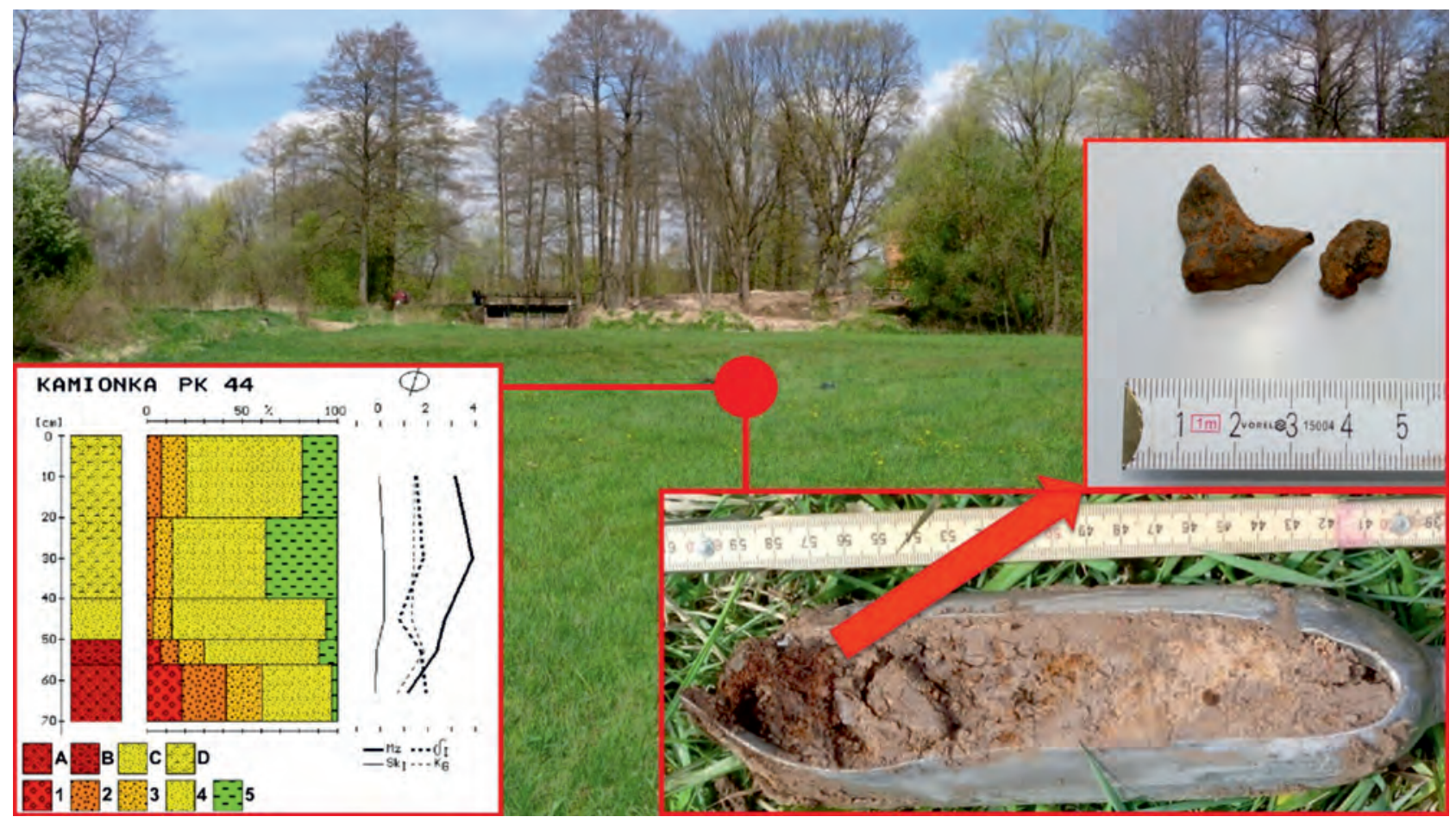

Ryc. 11. Odwiert wykonany w misie dawnego stawu w Jędrowie; Litologia: A - piasek ze żwirem, B - piasek ze żwirem zagliniony, C - piaski drobne, D - piaski zaglinione; frakcje: 1 - żwir $(<-1 \phi), 2$ - piaski grube $(-1-1 \phi), 3$ - piaski średnie $(1-2 \phi), 4-$ piaski drobne $(2-4 \phi), 5-$ pyły i iły $(>4 \phi)$; Parametry Folka-Warda: Mz - średnia średnica, $\delta_{1}$ - odchylenie standardowe, Sk - skośność, $\mathrm{K}_{\mathrm{G}}$ - kurtoza; (Przepióra 2017)

Fig. 11. Borehole made in the former pond area in Jędrów; lithology A - sand with gravels, B - silty sand with gravels, $C$ - fine sands, D - silty sands; fractions: 1 - gravels $(<-1 \phi) ; 2$ - coarse sands $(-1-1 \phi), 3$ - medium sands $(1-2 \phi), 4$ - fine sands $(2-4 \phi), 5-$ silts and clays $(>4 \phi)$; Folk-Ward's distribution parameters: $\mathrm{Mz}-$ mean size, $\delta_{1}-$ standard deviation, Sk - skewness, $\mathrm{K}_{\mathrm{G}}$ - kurtosis; (Przepióra 2017) 

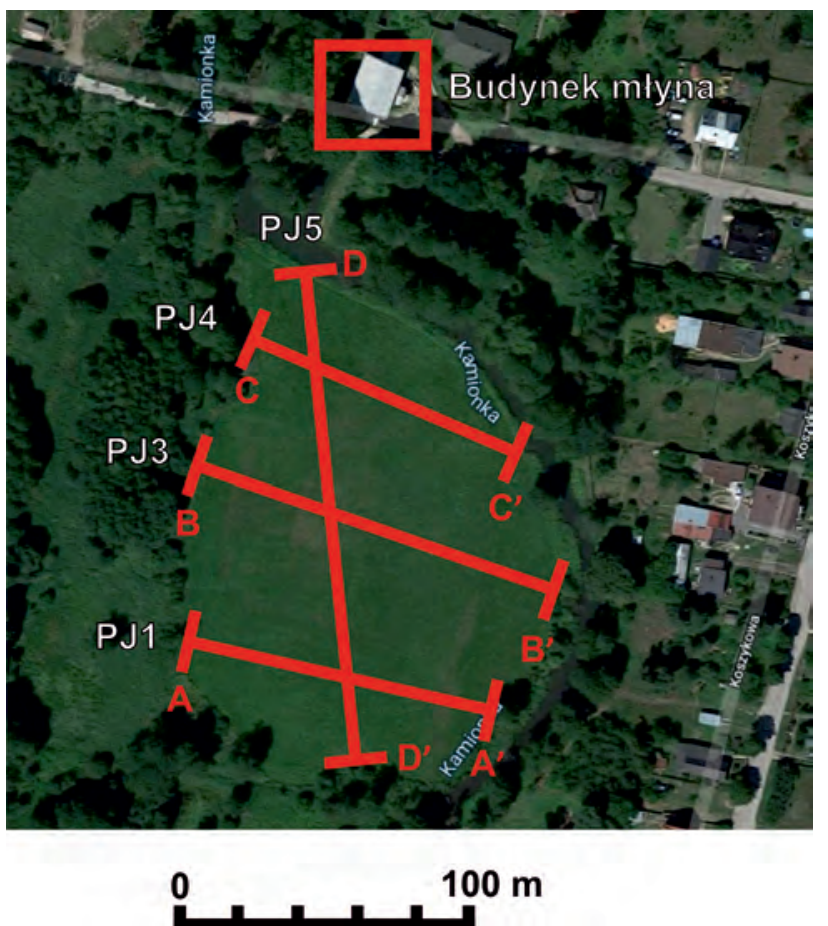

Ryc. 12. Rozmieszczenie echogramów w dnie misy dawnego stawu w Jędrowie na ortofotomapie (geportal.gov.pl)

Fig. 12. Location of the echograms in the bottom of the former pond in Jędrów area on an orthophotomap background (geportal.gov.pl)
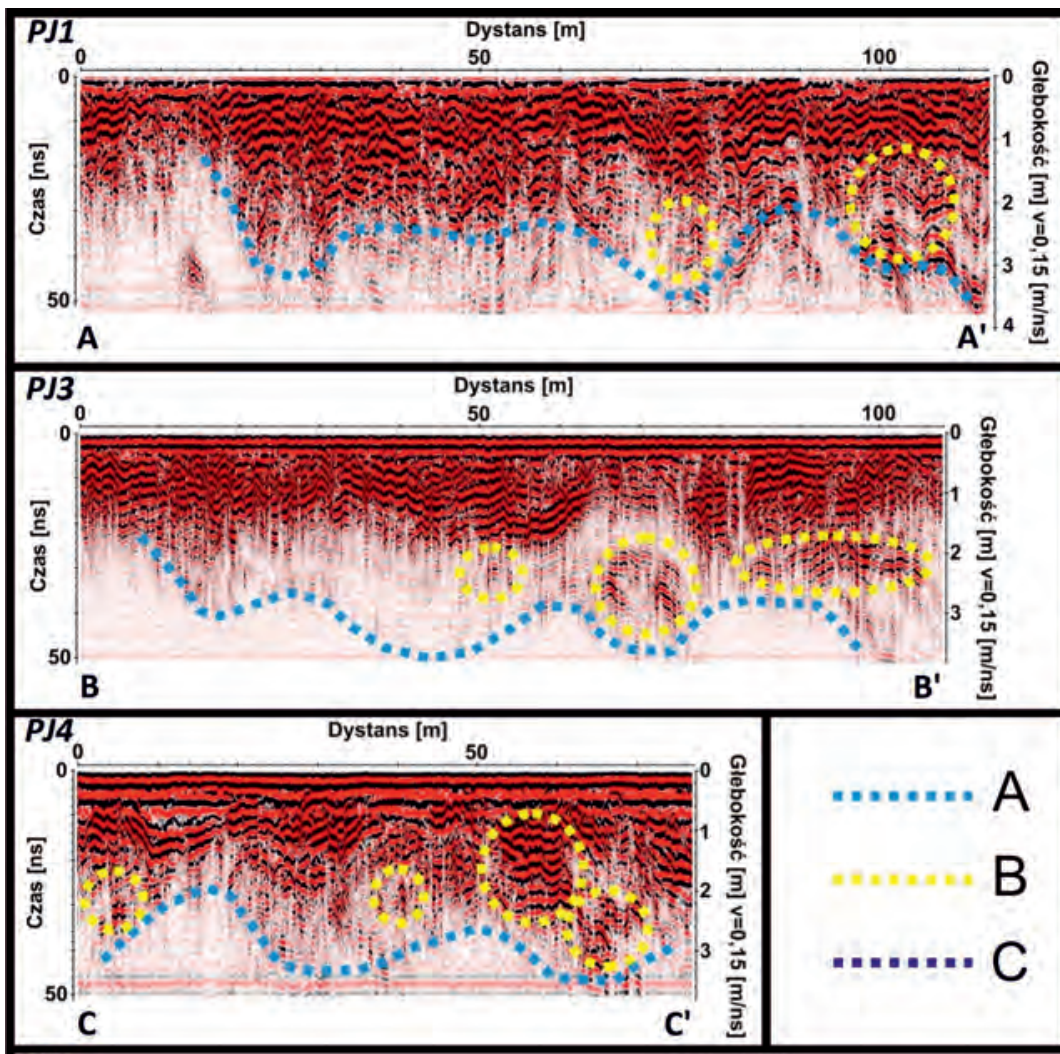

Ryc. 13. Echogramy wraz $z$ interpretacja; A - szacowane dno zbiornika wypełnionego osadami, B - mocny sygnał pochodzący najpewniej z zalegających w osadach żużli, C - wypłycenie, prawdopodobnie wał lub nasyp Fig. 13. Echograms with interpretation; A - estimated bottom of the water reservoir filled with sediments, B - a strong signal coming probably from the slag deposits in the sediments, $\mathrm{C}$ - the shallow area, probably dike or embankment

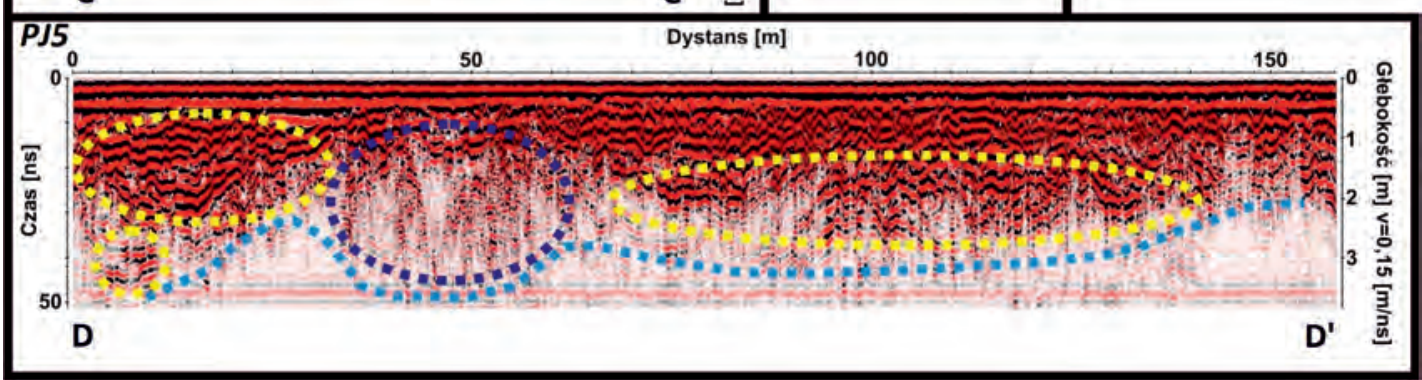


Przekrój PJ5 (ryc. 12, ryc. 13) jest przekrojem podłużnym misy zbiornika o orientacji NS. Jest on ułożony prostopadle do reszty echogramów i ma długość ok. 160 m. Maksymalny zasięg sygnału osiąga ok. $3 \mathrm{~m}$ głębokości. Na tym echogramie wyraźna jest anomalia, która rozciąga się od ok. $5 \mathrm{~m}$ do 22 na maksymalnej głębokości 2,8 m, a następnie wypłyca się do ok. 0,5 metra na 32. metrze, następnie widoczne jest ponowne pojawienie się kolejnych anomalii na tej samej głębokości, które ciągną się od 60. metra aż do końca przekroju.

Poniżej dawnego zbiornika w Jędrowie ok. 450 m w dół rzeki w pobliżu ujścia młynówki do Kamionki wykonano odwierty, z których pozyskano materiał do analizy makro- i mikrożużli. Wyniki tych analiz wykazały występowanie tutaj licznych, niewielkich (>212 $\mu \mathrm{m}$ ) fragmentów żużli zalegających w osadach pozakorytowych (ryc. 14C) oraz charakterystycznych, mikroskopijnych kulek żelaza (212-63 $\mu \mathrm{m})$, które zostały odseparowane przy pomocy magnesu (ryc. 14A, ryc. 14B). W jednym z odwiertów wykonanym w pobliżu krawędzi terasy plejstoceńskiej natrafiono na nagromadzenie dużych, kilkucentymetrowych fragmentów żużli występujących w osadach piaszczystych (żużlowisko?).
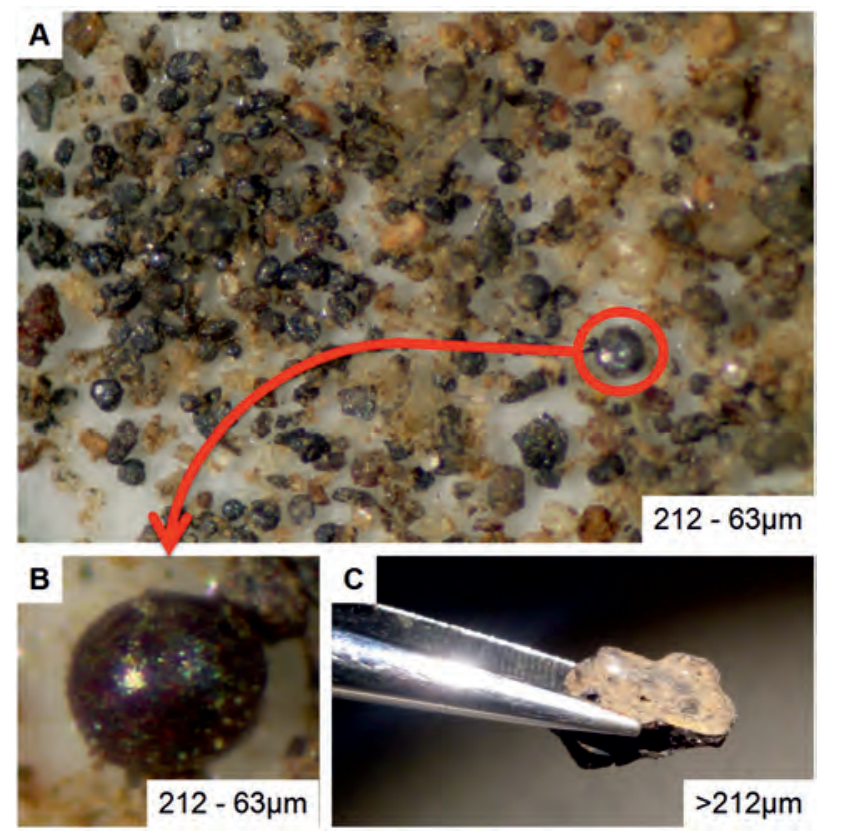

Ryc. 14. Resztki poprzemysłowe pochodzące z dawnej kuźnicy odkryte w osadach pozakorytowych ok. 450 m poniżej zbiornika w Jędrowie; A - mikroskopijne kulki żelaza pochodzenia antropogenicznego, B - zbliżenie, C - makroskopijne fragmenty żużla

Fig. 14. Post-industrial remains from the former forge discovered in overbank sediments about $450 \mathrm{~m}$ downstream of the Jędrów reservoir; A - microscopic iron balls of anthropogenic origin, B - close-up view, C- macroscopic slag fragments

\section{Dyskusja}

Na równinie zalewowej, na obszarze której znajduje się budynek młyna, zachował się szereg różnych elementów infrastruktury hydrotechnicznej (ryc. 10). Odbudowany został jaz i pomost, oczyszczono część młynówki, której całkowita długość przekracza $340 \mathrm{~m}$ i zrekonstruowano fragment ok. 100 metrowego wału. Budynek młyna wraz z bezpośrednio przyległymi obiektami hydrotechnicznymi również został odnowiony. W dobrym stanie zachowały się tu takie elementy infrastruktury hydrotechnicznej, jak ponad 300 metrowa młynówka i niecka 1,5 ha, obecnie zalądowionego stawu młyńskiego znajdującego się na południe od młyna.

Przez stulecia znajdował się tu staw przemysłowy (przy kuźnicy), o czym świadczą resztki poprzemysłowe (żużle, węgle drzewne) w osadach jeziornych oraz pozakorytowych. Występujące w osadach żużle są pozostałością po działalności kuźnicy, co potwierdzają badania z innych regionów Europy, m.in. z Ardenów (Houbrechts, Petit 2004, Houbrechts 2007, Notebaert i in. 2011). Po upadku przemysłu zbiornik ten był następnie wykorzystywany przez młyn wodny. Wiele podobnych stawów na Kamionce tworzyło antropogeniczny system małej retencji, co dodatkowo łagodziło ewentualne wezbrania na rzece (Kalicki i in. 2019c, 2019d). Obecnie obszar ten jest częścią równiny zalewowej. W pobliżu młyna zachowały się też stawy hodowlane (dwa powyżej młyna o rozmiarach ok. 85 i 75 arów i jeden 72 arowy poniżej) otoczone wciąż widocznymi w terenie wałami (łącznie ok. 900 m długości) (ryc. 3) wraz z ruinami upustu oraz resztki dawnej zapory, które tworzą bystrze w korycie Kamionki (ryc. 7). Należy podkreślić, że przez ostatnie stulecia teren wokół młyna nie był jednakowo zagospodarowany, o czym świadczą materiały kartograficzne. Natomiast widoczne są stawy (1801-1859) pojawiające się powyżej i poniżej młyna, które następnie znikają (1873-1927) i w ich miejscu pojawiają się kolejne, mniejsze (1938) (ryc. 6). Funkcjonowanie tych mniejszych stawów potwierdzają m.in. analizy georadarowe, które wykazały występowanie dwóch dużych anomalii oddzielonych wyraźnym wypłyceniem (wałem?), które są widoczne w echogramie PJ5 (najpewniej są to zagłębienia wypełnione osadami jeziornymi). Liczne mniejsze, ale wyraźne anomalie można wiązać z występowaniem w osadach jeziornych żużli pochodzących z okresu działalności kuźnicy w Jędrowie (ryc. 13). Przy zwartej pokrywie roślinnej w rozszyfrowaniu pozostałości infrastruktury hydrotechnicznej bardzo pomocny był numeryczny model terenu. Pozwolił on zinwentaryzować wklęsłe i wypukłe formy antropogeniczne. Tworzą one stosunkowo dobrze zachowany system infrastruktury hydrotechnicznej młyna i zapewne dawnej kuźnicy (ryc. 10).

Odkryte w osadach pozakorytowych liczne żużle i mikroskopijne kulki żelaza (mikrosfery) (ryc. 14) są doskonałym markerem świadczącym o funkcjonowaniu w najbliższej okolicy zakładu hutniczego (por. Richeedeau, 1977, Houbrechts, Petit 2006, Houbrechts 2007). Większe fragmenty żużla zalegają w osadach na różnych głębokościach, co świadczy o ich redepozycji przez ostatnie stulecia uregulowaną rzeką. Mniejsze, żelazne kulki, często puste w środku powstawały w wysokich temperaturach podczas wytapiania rudy żelaza w piecach zakładów hutniczych. Były one przenoszone przez wiatr, a następnie redeponowane i przykrywane osadami pozakorytowymi. Pochodzenie powstałych w osadach warstw poprzemysłowych zawierających m.in. węgielki drzewne potwierdzają daty OSL i ${ }^{14} C$, które wpisują się w działalność XIX w. kuźnicy w Jędrowie (Piasta 2012), jak również w okres wzmożonej działalności mielerzy, w których wytwarzano węgiel drzewny (Rutkiewicz i in. 2017, 2019). 


\section{Wnioski}

Młyn w Jędrowie jest jednym z niewielu tego typu obiektów w regionie świętokrzyskim, który zachował się $w$ tak dobrym stanie. Dotyczy to również samej infrastruktury hydrotechnicznej w jego najbliższym otoczeniu. Mimo że duża jej część już nie funkcjonuje, to jest ona nadal widoczna w rzeźbie, pozostałe zaś elementy dopiero są odkrywane przy pomocy numerycznego modelu terenu i szczegółowych analiz specjalistycznych (georadar). Podobnie jak wiele tego typu obiektów należących do Staropolskiego Okręgu Przemysłowego, bardzo czytelne są zachowane ślady po działalności metalurgicznej, na które można trafić w formach (żużlowisko, infrastruktura hydrotechniczna kuźnicy) oraz w osadach (makro- i mikrożużle, mikroskopijne kulki żelaza). Sam budynek został obecnie odrestaurowany przez nowych właścicieli i prace przywracające dawną świetność tego obiektu nadal trwają. Ponownie uruchomiono część odnowionej infrastruktury (jaz), co może prowadzić do kolejnych zmian w sposobie sedymentacji osadów poniżej młyna.

Obecny stan młyna przyczynił się do podjęcia czynności mających na celu wpisanie tego obiektu do rejestru zabytków i objęcia go ochroną konserwatorską. Jest to niezwykle ważne ze względu na ochronę zabytkowego młyna, ale i zachowania dziedzictwa przemysłu metalurgicznego Staropolskiego Okręgu Przemysłowego, który również pozostawił po sobie wyraźne ślady w okolicznym krajobrazie (Kalicki i in. 2019a).

\section{Podziękowania}

Serdeczne podziękowania kierujemy do Marcina Frączka, Ellynn Bertemes, Michała Aksamita oraz Pauliny Grzeszczyk za pomoc w pracach terenowych i laboratoryjnych. Szczególne podziękowania należą się Świętokrzyskiemu Wojewódzkiemu Konserwatorowi Zabytków, Pani Annie Żak, na której zlecenie wykonana została ekspertyza geoarcheologiczna. Również serdecznie dziękujemy Pani Annie Mazur-Orłowskiej i Piotrowi Orłowskiemu, obecnym właścicielom młyna w Jędrowie, którzy umożliwili przeprowadzenie badań w jego bezpośrednim otoczeniu.

\section{Literatura}

Aksamit, M., Kusztal, P., Kalicki, T., Grzeszczyk, P., Przepióra, P., 2019 Silting of the Sielpia water reservoir in the $20^{\text {th }}$ and $21^{\text {st }} \mathrm{C}$. (centra Poland). Geobalcanica Proceedings Book 2019, Physical Geography, 101-105.

Bielenin, K., 1993. Starożytne górnictwo i hutnictwo żelaza w Górach Świętokrzyskich. Kieleckie Towarzystwo Naukowe, Kielce, 10-12.

Chrabąszcz, M., Kalicki, T., Przepióra, P., Frączek, M., 2017. Zmiany koryta dolnej i środkowej Wiernej Rzeki od XVIII wieku. Acta Universitatis Lodziensis, Folia Geographica Physica 16, 5-13.

Chrzanowski, W., 1859. Karta dawnej Polski.

Filonowicz, P., 1978a. Objaśnienia do szczegółowej mapy geologicznej Polski 1:50000, ark. Skarżysko-Kamienna. Wydawnictwo Geologiczne, Warszawa.

Filonowicz, P., 1978b. Szczegółowa mapa geologiczna Polski w skali 1:50000, ark. Skarzysko-Kamienna. Wydawnictwo Geologiczne, Warszawa.

Herget, J., 1998. Anthropogenic influence on the development of the Holocene terraces of the river Lippe, Germany, [w:] Benito, G., Baker, V.R., Gregory, K.J. (red.), Palaeohydrology and environmental change. Wiley, Chichester, 167-179.

Houben, P., Wunderlich, J., Schrott, L., 2009. Climate and long-term human impact on sediment fluxes in watershed systems. Geomorphology 108(1-2), 1-7.
Houbrechts, G., 2007. La sidérurgie proto-industrielle dans le bassin de la Lienne. De la Meuse à I'Ardenne, Entre Ardenne et Meuse ASBL, 39, 34-63.

Houbrechts, G., Petit, F., 2003. Utilisation des scories métallurgiques en dynamique fluviale: détermination de la compétence effective des rivières et estimation des vitesses de progression de leur charge de fond/Utilisation of metallurgie slags for the study of fluvial dynamics: determination of the effective competency of rivers and estimation of the transit time of sedimentary waves. Géomorphologie: Relief, Processus, Environnement, Janvier-mars, 9(1), 3-12.

Houbrechts, G., Petit, F., Kalicki, T., 2003. Metallurgic slags of the last centuries as a tracer in archaeological and palaeogeographical studies in Arden (Belgium). Final Programme and Abstracts of $9^{\text {th }}$ Annual Meeting of European Association of Archaeologists, $10^{\text {th }}-14^{\text {th }}$ September 2003, St. Petersburg, 17-18.

Houbrechts, G., Petit, F., 2004. Evolution des techniques sidérurgiques pré-industrielles et aperçu des critères de localisation de la métallurgie en «Terre de Durbuy». Terre de Durbuy 89, 3-29.

Houbrechts, G., Petit, F., Kalicki, T., 2004. Rozwój metalurgii a sedymentacja fluwialna z ostatnich stuleci w ardeńskich dopływach Mozy (Belgia), [w:] Michalczyk, Z. (red.), Badania geograficzne w poznawaniu środowiska. Lublin, 192-194.

Houbrechts, G., Petit, F., 2006. Utilisation des microscories métallurgiques comme traceur de la sédimentation dans les plaines alluviales des rivières ardennaises. University of Liege, 95-98.

Kalicki, T., 2006. Zapis zmian klimatu oraz działalności człowieka i ich rola w holoceńskiej ewolucji dolin środkowoeuropejskich. Prace Geograficzne IGiPZ PAN 204, Warszawa.

Kalicki, T., Przepióra, P., Podrzycki, Ł., 2017. Osady i wiek wyższej terasy Kamionki na odcinku Suchedniów-Rejów. Acta Geographica Lodziensia 106, 53-64.

Kalicki, T., Przepióra, P. (przy współpr. z Chwałkiem, S. i Frączkiem, M.) 2019a. Lokalizacja oraz zasięg historycznego układu hydrotechnicznego z młynem wodnym w Jędrowie (obecnie: ul. Koszykowa 18b w Suchedniowie) - ekspertyza geoarcheologiczna. Zlecone przez Wojewódzkiego Konserwatora Zabytków w Kielcach.

Kalicki, T., Chrabąszcz, M., Frączek, M., Fularczyk, K., Kłusakiewicz, E., Kusztal, P., Malęga, E., Przepióra, P., 2019b. Zapis zmian antropogenicznych w formach i osadach dolin świętokrzyskich, [w:] Żeber-Dzikowska, I., Chmielewski, J. (red.), Środowisko - współczesne dylematy/Environment - contemporary dilemmas. Instytut Ochrony Środowiska - Państwowy Instytut Badawczy, Warszawa, 247-280.

Kalicki, T., Frączek, M., Przepióra, P., Kusztal, P., Kłusakiewicz, E., Malęga, E., 2019c. Late Quaternary geomorphology and geoarchaelogy in the rivers of the Holy Cross Mountains region, Central Europe. Quaternary Research 91 (2), 584-599.

Kalicki, T., Przepióra, P., Aksamit, M., Frączek, M., Kłusakiewicz, E., Grzeszczyk, P., 2019d. Forming and disappearance of small retention system in the postindustrial area - case study from the central section of the Kamionka river valley (Central Poland) since the $18^{\text {th }}$ century. Acta Geobalcanica 5 (1), 29-34.

Kaniecki, A., 1999. Młyny wodne w dawnym Poznaniu i ich wpływ na przeobrażenie stosunków wodnych. Acta Universitatis Nicolai Copernici, Geografia 29, Uniwersytet Mikołaja Kopernika, Toruń.

Klimek, K., 1999. A 1000 year alluvial sequence as an indicator of catchment/floodplain interaction: the Ruda valley, Sub-Carpathians, Poland, [w:] Brown, A.G., Quine, T.A. (red.), Fluvial processes and environmental change. Wiley, 329-343.

Klimek, K., 2003. Sediment transfer and storage linked to Neolithic and Early Medieval soil erosion in the Upper Odra Basin, southern Poland, [w:] Howard, A.J., Macklin, M.G., Passmore, D.G. (red.), Alluvial Archaeology in Europe. Swets \& Zeitlinger, Lisse, 251-259.

Kondracki, J., 1977. Regiony fizycznogeograficzne Polski. Wydawnictwo Uniwersytetu Warszawskiego, Warszawa.

Kondracki, J., 2002. Geografia regionalna Polski. Wydawnictwo Naukowe PWN, Warszawa.

Krupa, J., 2013. Naturalne i antropologiczne procesy kształtujące dno doliny Czarnej Nidy w późnym vistulianie i holocenie. Folia Quaternaria 81, 5-156. 
Krupa, J., 2015. Natural and anthropogenic channel pattern changes in the mid-mountain valley during the Late Glacial and Holocene, Polish Uplands. Quaternary International 370, 55-65.

Kusztal, P., Kalicki, T., Chrabąszcz, M., Frączek, M., Kłusakiewicz, E., Przepióra, P., Zaborska, D., 2017a. Powstanie i zanik małej retencji w ostatnich stuleciach na przykładzie wybranych dolin w Świętokrzyskiem. Książka abstraktów Ogólnopolskiej Konferencji „Nauka Okiem Młodego Naukowca". Promovendi, Łódź, s. 21.

Kusztal, P., Kalicki, T., Chrabąszcz, M., Frączek, M., Kłusakiewicz, E., Przepióra, P., Zaborska, D., 2017b. Nowożytne zakłady hutnicze i młyny a rozwinięcie koryta Czarnej Koneckiej powyżej zalewu w Sielpi (region świętokrzyski), [w:] Brykała, D., Prarat, M., Lamparski, P. (red.), Materiały Konferencyjne Interdyscyplinarnego Seminarium Naukowego „Młyny wodne w dorzeczu dolnej Wisły od początku XVIII do początku XXI wieku". Uniwersytet Mikołaja Kopernika, Toruń, s. 46.

Łoś, M.J., 1978. Likwidacja młynów wodnych i jej skutki. Gospodarka Wodna 38 (12). Wydawnictwo PWN, Warszawa, 361-364.

Macklin, M.G., Passmore, D.G., Rumsby, B.T., 1992. Climatic and cultural signals in Holocene alluvial sequences: the Tyne basin, northern England, [w:] Needhan, S., Macklin, M.G. (red.), Alluvial archaeology in Britain. Oxbow Monograph 27, 123-139.

Marchetti, M., 2002. Environmental changes in the central Po Plain (northern Italy) due to fluvial modifications and anthropogenic activities. Geomorphology 44 (3-4), 361-373.

Mięsiak-Wójcik, M., 2018. Analysis of water retention changes in selected lake-wetland catchments of West Polesie based on historical documents. Limnol. Rev. 18(2), 59-75.

Notebaert, B., Houbrechts, G., Verstraeten, G., Broothaerts, N., Haeckx, J., Reynders, M., Govers, G., Petit, F., Poesen, J., 2011. Fluvial architecture of Belgian river systems in contrasting environments: Implications for reconstructing the sedimentation history. Netherlands Journal of Geosciences - Geologie en Mijnbouw. 90 (1), 31-50.

Notebaert, B., Verstraeten, G., Houbrechts, G., Petit, F., 2013. Holocene floodplain deposition and scale effects in a typical European upland catchment: A case study from the Amblève catchment, Ardennes (Belgium). The Holocene 23 (8), 1184-1197.
Orzechowski, S., 2007. Zaplecze osadnicze i podstawy surowcowe starożytnego hutnictwa świętokrzyskiego. Kieleckie Towarzystwo Naukowe, Kielce.

Piasta, S., 2012. Leksykon Suchedniowa. Towarzystwo Przyjaciół Suchedniowa, Kielce.

Podgórski, Z., 2004. Wpływ budowy i funkcjonowania młynów wodnych na rzeźbę terenu i wody powierzchniowe Pojezierza Chełmińskiego i przyległych części dolin Wisły i Drwęcy. Uniwersytet Mikołaja Kopernika, Toruń.

Przepióra, P., 2017. Naturalne i historyczne zmiany zlewni Kamionki (Płaskowyż Suchedniowski) w subatlantyku. Maszynopis pracy doktorskiej, Uniwersytet Jana Kochanowskiego, Kielce.

Przepióra, P., Kalicki, T., 2018. Zmiany koryta Kamionki (Płaskowyż Suchedniowski) na odcinku Ostojów-Rejów od XVIII wieku w oparciu o archiwalne materiały kartograficzne. Acta Universitatis Lodziensis, Folia Geographica Physica 17, 25-32.

Richeedeau, C., 1977. Distribution des sphèrules magnèticues provenant de la sidèrurgie liègeoise, dans B.S.G. Lg, 13, 155-165.

Rutkiewicz, P., Malik, I., Wistuba, M., Sady, A., 2017. Charcoal kilns as a source of data on past iron industry (an example from the Czarna River valley, Central Poland). Environ. Socio.-Econ. Stud. 5(3), 12-22.

Rutkiewicz, P., Malik, I., Wistuba, M., Osika, A., 2019. High concentrations of charcoal hearth remains as legacy of historical ferrous metallurgy in southern Poland. Quaternary International 512, 133-143.

Schirmer, W., 1995. Valley bottoms in the Late Quaternary, [w:] Hagedorn, J. (red.), Late Quaternary and present-day fluvial processes in Central Europe. Zeitschrift f. Geomorphologie, Suppl.-Bd. 100, 27-51.

Starkel, L., Krąpiec, M., 1995. Profile of the alluvia with „black oaks" in Kędzierz on the Wisłoka river, [w:] Starkel, L. (red.), Evolution of the Vistula river valley during the last 15000 years, part V. Geographical Studies, Special Issue 8, 101-110.

www.geoportal.gov.pl.

Zannoni, R., 1772. Carte de la Pologne.

Zieliński, J., 1965. Staropolskie Zagłębie Przemysłowe. Kieleckie Towarzystwo Naukowe, Ossolineum, s. 339. 